\title{
Radioprotective Effects of Histamine H2 Receptor Antagonists Famotidine and Ranitidine on Gamma-Ray Induced Chromosome Aberration and Micronuclei in vitro in Human Lymphocytes
}

\author{
Narinder Kumar Sharma \\ Radiation Biology and Health Sciences Division, Bio-Sciences Group, Bhabha Atomic Research Centre, Mumbai, India
}

\section{Email address:}

nksharma@barc.gov.in

\section{To cite this article:}

Narinder Kumar Sharma. Radioprotective Effects of Histamine H2 Receptor Antagonists Famotidine and Ranitidine on Gamma-Ray Induced Chromosome Aberration and Micronuclei in vitro in Human Lymphocytes. American Journal of BioScience.

Vol. 3, No. 6, 2015, pp. 249-255. doi: 10.11648/j.ajbio.20150306.17

\begin{abstract}
Histamine $\mathrm{H} 2$ receptor antagonist are used in the clinical treatment of peptic ulcer. In vitro metaphase analysis and micronucleus assay were used to test the effect of Famotidine \& Ranitidine on ${ }^{60}$ Cobalt gamma-ray induced clastogenic effects. Heparinised whole blood was obtained from 6 healthy volunteers and was gamma irradiated with 3Gy. Lymphocyte cultures were initiated and aqueous solution of Famotidine $(150 \mu \mathrm{g} / \mathrm{ml}) \&$ Ranitidine $(500 \mu \mathrm{g} / \mathrm{ml})$ was added at $0 \mathrm{~h}$ and $24 \mathrm{~h}$. Cultures were harvested \& processed at $48 \mathrm{~h} \& 72 \mathrm{~h}$ for chromosome aberrations and micronucleus analysis respectively. At $0 \mathrm{~h} \& 24 \mathrm{~h}$ after 3Gy gamma irradiation, cultures treated with Famotidine \& Ranitidine independently showed significant decrease $(\mathrm{p}<$ 0.0001 ) in the frequency of chromosome aberration. At $0 \mathrm{~h} \& 24 \mathrm{~h}$ Famotidine induced $60.91 \%$ \& $56.42 \%$ inhibition in dicentrics \& $59.39 \%$ \& $56.21 \%$ inhibition was observed in total aberrations where as Ranitidine induce $52.11 \%$ \& $43.54 \%$ inhibition in dicentrics and $53.06 \%$ \& $46.66 \%$ inhibition in total aberrations at $0 \mathrm{~h} \& 24 \mathrm{~h}$. Significant decrease in the frequency of micronuclei was observed with Famotidine treatment after 3Gy of gamma irradiation, which induced inhibition of $48.83 \%$ $(\mathrm{p}<0.0001)$ at $0 \mathrm{hr} \& 5.02 \%(\mathrm{p}<0.016)$ at $24 \mathrm{~h}$. However, Ranitidine induced significant decrease $(\mathrm{p}<0.0001)$ in frequency of micronuclei of $28.85 \%$ at $0 \mathrm{~h}$ where as a decrease in frequency was observed of $2.88 \%$ at $24 \mathrm{~h}$ although not significant when compared with $3 \mathrm{~Gy}$ gamma irradiation alone. In conclusion radio protective effects of Histamine $\mathrm{H} 2$ receptor antagonists Famotidine and Ranitidine was observed on exposure to gamma-ray.
\end{abstract}

Keywords: Ionizing Radiation, Radioprotection, Chromosomal Aberration, Cytochalasin-B Blocked Micronuclei, Histamine H2 Receptor Antagonist, Famotidine, Ranitidine, Human Lymphocytes

\section{Introduction}

The use of chemical agents and phytochemicals to provide protection against radiation induced injuries has been a major field of study over 50 years. The focus of radiobiological research is to protect living organisms from radiation-induced damage. Ionizing radiation causes damage to living cells through a series of molecular events. Interaction of radiation with cell component such as DNA, have a prime biological significance on cells. Since ionizing radiation as a physical mutagen induces a variety of lesions in DNA such as SSB, DSB or clustered damages, quantification of these damages seems to be a good bio-indicator for ionizing radiation [1].

The search for more effective and less toxic radioprotectors has spurred interest in the development of different compounds. The compounds should be safe and non-toxic radio protectors which provide enough protection at a lower concentration and more tolerable in humans. Since the introduction of Cysteine as a radio protector in 1949 [2, 3], various types of natural and synthetic chemicals were tested for their radioprotective properties on various biological systems with different end points. Histamine $\mathrm{H} 2$ receptor antagonist also known as $\mathrm{H} 2$ blocker are class of drug which are used to block the action of histamine on parietal cells in stomach thus decreasing acid production by these cells. These drugs are potent scavengers of oxygen radicals, good inhibitors of histamine - stimulated gastric acid secretion, have capability for gastric acid suppression and the pepsin secretion 
and in addition are potent $\&$ highly powerful hydroxyl-radical scavengers [4]. Histamine H2 receptor antagonist such as Cimetidine, Famotidine and Ranitidine are used in the clinical treatment of peptic ulcer. It was shown that $\mathrm{H} 2$ receptor antagonists such as Cimetidine and Famotidine exert radioprotective effects in human peripheral blood lymphocytes. [5,6]. Among them, Famotidine and Ranitidine are readily available in the market, economical and non-toxic at therapeutic doses administered. It can be administered orally. These properties of Famotidine and Ranitidine make it promising as a radioprotector for clinical use. Thus an attempt has been made to examine Famotidine and Ranitidine against gamma radiation induced DNA damage. The present study is conducted using metaphase chromosome for chromosome aberration and micronuclei analysis in order to examine the radioprotective effects of histamine $\mathrm{H} 2$ receptor antagonists on gamma rays induced clastogenic effects in vitro on human peripheral blood lymphocytes.

\section{Materials and Methods}

\subsection{Sample Collection \& Processing}

Informed consents were obtained from 6 healthy male volunteers in the age group of 26-38 years with the inclusion criteria of having no history of exposure to clastogens, no smoking, tobacco chewing, alcohol consumption or drug taking. Blood samples were drawn from these volunteers under sterile conditions in heparinised vacutainer tubes. $0.3 \mathrm{ml}$ of whole blood was cultured in $4.5 \mathrm{ml}$ Ham's F10 (Sigma) medium supplemented with $15 \%$ fetal calf serum (Sigma) and L-glutamine. Cell cultures were initiated with addition of $0.1 \mathrm{ml}$ of phytohemaglutinin (PHA) (Sigma) at a final concentration of $5 \mu \mathrm{g} / \mathrm{ml}$ as mitogen to each culture vessel. No antibiotics were added to the cultures at any stage. Cultures were incubated at $37^{\circ} \mathrm{C}$. This culture protocol was followed for CBMN. Briefly, at $24 \mathrm{~h}$ after culture initiation, cytochalasin $\mathrm{B}$ was added, resulting in a final concentration of $6 \mu \mathrm{g} / \mathrm{ml}$ in the cultures [7].

\subsection{Drug Usage}

Famotidine tablets USP 20mg (Famotin*20) (Mfd. By USV Limited Mumbai India) and Ranitidine Hydrochloride Tablet IP (Zinetac*150mg) (Mfd. By GlaxoSmithKline Pharmaceutical Limited Nashik, India), were purchased from local market. Tablets were crushed and dissolved in double distilled water to get aqueous solution of Famotidine (150 $\mu \mathrm{g} / \mathrm{ml})$ and Ranitidine $(500 \mu \mathrm{g} / \mathrm{ml})$ which were filtered sterilized.

\subsection{Irradiation of Blood Samples}

Blood samples were irradiated with ${ }^{60} \mathrm{Co}$ gamma rays at $3 \mathrm{~Gy}$ (dose rate of $0.77 \mathrm{~Gy} / \mathrm{min}$ (Teletherapy Machine Theratron Junior ${ }^{60} \mathrm{Co}$ Machine). Cultures were set from the un-irradiated and irradiated blood samples as per the standard protocol [7].

\subsection{Study Design}

\subsubsection{The Following Sets of Experiments Were Conducted.}

Set $\boldsymbol{I}-0.3 \mathrm{ml}$ of irradiated whole blood was innoculated into $5 \mathrm{ml}$ of reconstituted culture medium for $\mathrm{CA}$ analysis and the following groups were included: (a) control (un-irradiated whole blood), (b) un-irradiated whole blood + FAM $150 \mu \mathrm{g} / \mathrm{ml}$ or RAN $500 \mu \mathrm{g} / \mathrm{ml} 0 \mathrm{~h}$ and $24 \mathrm{~h} \mathrm{(c)}{ }^{60}$ Cobalt gamma radiation $3 \mathrm{~Gy}$ irradiated whole blood (d) ${ }^{60}$ Cobalt gamma radiation 3 Gy irradiated whole blood + FAM $150 \mu \mathrm{g} / \mathrm{ml}$ or RAN $500 \mu \mathrm{g} / \mathrm{ml} 0 \mathrm{~h}$ and $24 \mathrm{~h}$; total duration $48 \mathrm{~h}$ (demecolcine added at $45 \mathrm{~h}$ ).

Set II $-0.3 \mathrm{ml}$ of irradiated whole blood was inoculated into $5 \mathrm{ml}$ of reconstituted culture medium for $\mathrm{MN}$ analysis and the following groups were included: (a) control (unirradiated whole blood), (b) un-irradiated whole blood + FAM $150 \mu \mathrm{g} / \mathrm{ml}$ or RAN $500 \mu \mathrm{g} / \mathrm{ml} 0 \mathrm{~h}$ and $24 \mathrm{~h}$ (c) ${ }^{60} \mathrm{Cobalt}$ gamma radiation $3 \mathrm{~Gy}$ irradiated whole blood (d) ${ }^{60} \mathrm{Cobalt}$ gamma radiation $3 \mathrm{~Gy}$ irradiated whole blood + FAM $150 \mu \mathrm{g} / \mathrm{ml}$ or RAN $500 \mu \mathrm{g} / \mathrm{ml} 0 \mathrm{~h}$ and $24 \mathrm{~h}$, total duration $72 \mathrm{~h}$ (cytochalasin B $6 \mu \mathrm{g} / \mathrm{ml}$ added at $24 \mathrm{~h}$ ).

Forty-eight hours after culture initiation, $0.2 \mu \mathrm{g} / \mathrm{ml}$ demecolcine (Sigma) was added to the cultures for $2 \mathrm{~h}$ to arrest cells at metaphase. Cells were harvested and exposed to hypotonic solution $(\mathrm{KCl}, 0.075 \mathrm{M})$ for 12 minutes, then fixed in Carnoy's fixative (3:1 v/v Methanol : Glacial acetic acid). Slides were prepared using air drying technique and stained in $2 \%$ Giemsa solution (Merck). For cytoknesis blocked micronuclei assay, cells were harvested at $72 \mathrm{~h}$ following a $5 \mathrm{~min} 0.8 \%$ cold $\mathrm{KCl}$ treatment and fixation, including $1 \%$ formaldehyde in the second fixative. Cells were stained with $1 \%$ Giemsa (Merck) in Sorensen's buffer, pH 6.8, for $20 \mathrm{~min}[8,9,10]$.

200 mitoses were analyzed for the presence or absence of chromosomal aberrations for each treatment. Lesions were classified according to the international system of cytogenetic nomenclature for acquired chromosome aberrations (ISCN 1985) [11]. Major chromosomal aberrations observed in this study were of chromosome types including isochromatid gaps, isochromatid breaks and chromosomal exchanges, mainly of dicentric type.

Cytogenetic analysis was carried out incorporating the Chromososme and Micronucleus Analysis

\subsection{Chromosome Aberration Assays}

The stained preparations were examined for unstable CAs [12]. CAs was scored from 100 well-spread metaphases with a minimum of 46 centromeres and 50 metaphases per slide under oil immersion at $100 \mathrm{X}$ magnification.

\subsection{Cytochalasin B Blocked Micronuclei Assays}

Total numbers of micronucleated binucleated cells $(\mathrm{MNBN})$ and total number of $\mathrm{MN}$ were determined in 1000 binucleated cells with well-preserved cytoplasm. The nuclear division index (NDI) was determined by scoring the number of mononucleate, binucleate, trinucleate, tetranucleate and more (polynucleate) cells in 1000 viable cells. The nuclear 
division index (NDI) was calculated as:

$$
\mathrm{NDI}=\frac{[\mathrm{M} 1+(2 \times \mathrm{M} 2)+(3 \times \mathrm{M} 3)+(4 \times \mathrm{M} 4)]}{n}
$$

where M1 to M4 represent the number of cells with 1 to 4 nuclei respectively; $\mathrm{n}$ is the total number of cells scored [9, $10,13]$.

In order to study the radioprotective capability of Famotidine and Ranitidine, Chromosome aberration and CBMN assay was carried out in blood sample of 6 donors.

\section{Result \& Observations}

\subsection{Dicentric and Total Aberration Analysis}

The frequencies of chromosome and chromatid breaks were found to be $0 \%$ in control cultures. Tables I and Figure 1 represents frequency of dicentrics and total aberration obtained with various treatment and Table II and Figure 2 represents the percent inhibition with various treatment in human lymphocytes in 6 individual donors. Cultures treated with 3Gy gamma irradiation showed frequency of dicentrics to be $119+5.68$ and total aberrations to be $124+6.10$. After 3 Gy gamma irradiation, Famotidine showed a significant decrease $(\mathrm{p}<0.0001)$ in dicentrics and total aberrations at $0 \mathrm{~h}$ and $24 \mathrm{~h}$. The frequency of dicentrics and total aberrations observed was $46.50+2.14$ and $50.50+3.45 / 100$ cell at $0 \mathrm{~h}$ and $52.67+2.33$ and $54.33+2.94 / 100$ cells at $24 \mathrm{~h}$. Famotidine induced $60.91 \%$ and $56.42 \%$ inhibition in dicentrics and $59.39 \%$ and $56.21 \%$ inhibition in total aberrations respectively. At $0 \mathrm{~h}$ and $24 \mathrm{~h}$, Ranitidine after $3 \mathrm{~Gy}$ gamma irradiation revealed a significant decrease $(\mathrm{p}<$ 0.0001 ) in dicentrics and total aberrations. The frequency of dicentrics and total aberrations was observed to be $56.17+$ 2.2.80 and $58.17+2.82 / 100$ cell for $0 \mathrm{~h}$, and $67.17+3.13$ and $67.33+3.26 / 100$ cells for $24 \mathrm{~h}$. Ranitidine induced $52.09 \%$ and $45.54 \%$ inhibition in dicentrics and $53.06 \%$ and $45.66 \%$ inhibition in total aberrations respectively. The distribution analysis was carried out and was found to be poissonian. The dispersion index and $U$ values confirmed the distribution to be a Poisson distribution.

Table I. Frequency of Dicentrics and Total aberration per 100 cells analyzed in human lymphocytes following gamma irradiation in the absence or presence of Famotidine (FAM) and Ranitidine (RAN) at $0 \mathrm{~h}$ and $24 \mathrm{~h}$ of six donors.

\begin{tabular}{|c|c|c|c|c|c|c|c|c|c|c|c|c|}
\hline Donors & 1 & & 2 & & 3 & & 4 & & 5 & & 6 & \\
\hline & Dic & TA & Dic & TA & Dic & TA & Dic & $\mathbf{T A}$ & Dic & TA & Dic & TA \\
\hline Control & 0 & 0 & 0 & 0 & 0 & 1 & 0 & 0 & 0 & 0 & 0 & 0 \\
\hline FAM 0h & 0 & 2 & 0 & 0 & 0 & 0 & 0 & 0 & 0 & 0 & 0 & 0 \\
\hline FAM $24 \mathrm{~h}$ & 0 & 4 & 0 & 1 & 0 & 0 & 0 & 1 & 0 & 0 & 0 & 0 \\
\hline RAN 0h & 0 & 2 & 0 & 0 & 0 & 0 & 0 & 0 & 0 & 0 & 0 & 0 \\
\hline RAN 24h & 0 & 0 & 0 & 1 & 0 & 0 & 0 & 1 & 0 & 0 & 0 & 0 \\
\hline $3 \mathrm{~Gy}+\mathrm{FAM} 0 \mathrm{~h}$ & 47 & 54 & 51 & 63 & 40 & 42 & 54 & 56 & 43 & 43 & 44 & 45 \\
\hline $3 \mathrm{~Gy}+\mathrm{FAM} 24 \mathrm{~h}$ & 52 & 59 & 56 & 59 & 45 & 47 & 61 & 64 & 48 & 48 & 49 & 49 \\
\hline $3 \mathrm{~Gy}+\mathrm{RAN} 0 \mathrm{~h}$ & 57 & 58 & 62 & 63 & 49 & 50 & 67 & 69 & 53 & 53 & 54 & 56 \\
\hline $3 \mathrm{~Gy}+\mathrm{RAN} 24 \mathrm{~h}$ & 67 & 67 & 73 & 73 & 58 & 58 & 79 & 80 & 62 & 62 & 64 & 64 \\
\hline
\end{tabular}

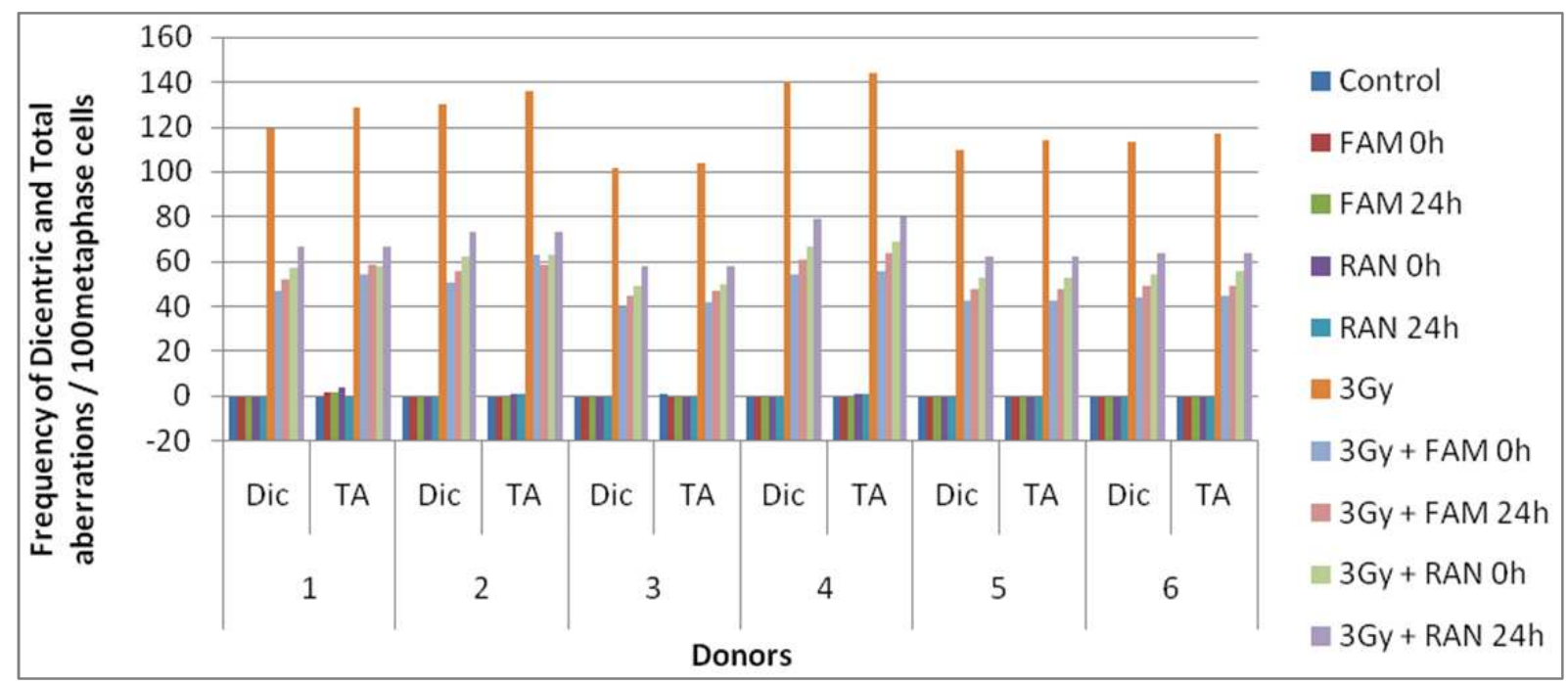

Fig. 1. Frequency of Dicentric and Total aberrations per 100 metaphase cells among the six donors following 3 Gy of gamma irradiation in the absence or presence of various doses of Famotidine (FAM) and Ranitidine (RAN) at Oh and $24 \mathrm{~h}$ [Y axis represents frequency of Dicentric and Total aberrations per 100 metaphase cells and $X$ axis represents six donors frequency of Dicentric and Total aberrations]. 
Table II. Percent Inhibition of Dicentrics and Total aberrations analyzed in human lymphocytes following gamma irradiation and Famotidine (FAM) or Ranitidine (RAN) treatment at $0 \mathrm{~h}$ and $24 \mathrm{~h}$ among the six donors.

\begin{tabular}{|c|c|c|c|c|c|c|c|c|}
\hline \multirow{3}{*}{ Donor } & \multicolumn{8}{|c|}{ \% Inhibition } \\
\hline & \multicolumn{2}{|c|}{ 3Gy + FAM 0h } & \multicolumn{2}{|c|}{ 3Gy + FAM 24h } & \multicolumn{2}{|c|}{ 3Gy + RAN 0h } & \multicolumn{2}{|c|}{ 3Gy + RAN 24h } \\
\hline & Dic & TA & Dic & TA & Dic & TA & Dic & TA \\
\hline 1 & 60.50 & 58.13 & 56.30 & 54.26 & 52.10 & 55.04 & 43.69 & 48.06 \\
\hline 2 & 60.76 & 53.68 & 56.92 & 56.62 & 52.30 & 53.68 & 43.85 & 46.32 \\
\hline 3 & 60.78 & 59.61 & 55.88 & 54.81 & 51.96 & 51.92 & 43.14 & 44.23 \\
\hline 4 & 61.42 & 61.11 & 56.43 & 55.55 & 52.14 & 52.08 & 43.57 & 44.44 \\
\hline 5 & 60.91 & 62.28 & 56.36 & 57.89 & 51.82 & 53.51 & 43.64 & 45.61 \\
\hline 6 & 61.06 & 61.54 & 56.64 & 58.12 & 52.21 & 52.14 & 43.36 & 45.30 \\
\hline
\end{tabular}

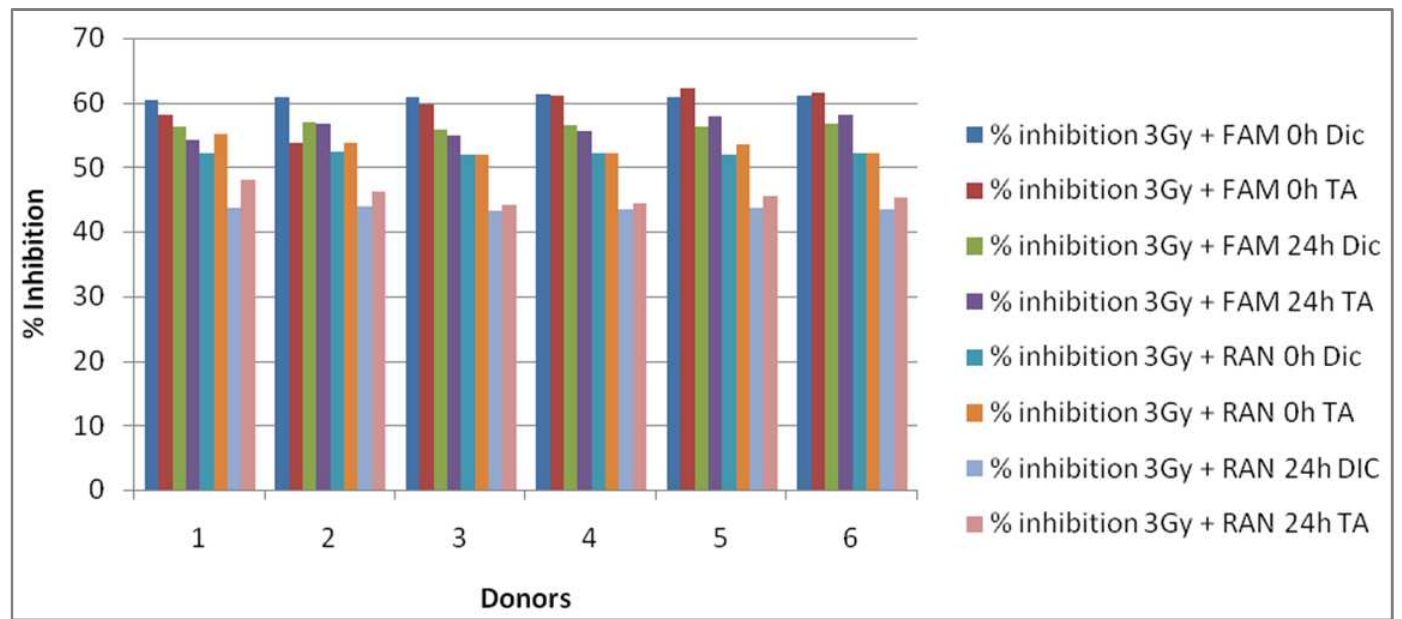

Fig. 2. Percent Inhibition of Dicentrics and Total aberrations analyzed in human lymphocytes following gamma irradiation in the absence or presence of various doses of Famotidine (FAM) and Ranitidine (RAN) in 6 donors. [Y axis represents \% inhibition and X axis represents six donors].

\subsection{Micronuclei Analysis}

Frequency of micronuclei analyzed in human lymphocytes following gamma irradiation in the absence or presence of Famotidine (FAM) and Ranitidine (RAN) and with various treatments is depicted in Tables III and figure 3 and percent inhibition with various treatments in human lymphocytes in 6 individual donors is represented in Table IV and figure 4. Tables III and Figure 3 represents frequency of Micronuclei per cell at various treatment and total number of binucleated cells scored were 1000. Table IV and Figure 4 represents the percent inhibition in micronuclei with various treatment.

Cultures treated with $3 \mathrm{~Gy}$ gamma irradiation showed a frequency of $1.010+0.01366$ micronuclei in binucleate cells. At $0 \mathrm{~h}$ and $24 \mathrm{~h}$, Famotidine after $3 \mathrm{~Gy}$ gamma irradiation revealed a significant decrease $(\mathrm{p}<0.0001$ for $0 \mathrm{~h} \& \mathrm{p}<$
0.016 for $24 \mathrm{~h}$ ) in micronuclei in binucleate cells. The frequency of micronuclei was observed to be $0.52+0.0074$ and $0.96+0.0083 / \mathrm{BN}$ cell, and $48.83 \%$ and $5.02 \%$ inhibition in micronuclei at $0 \mathrm{~h}$ and $24 \mathrm{~h}$ respectively. After 3Gy gamma radiation, Ranitidine showed a significant decrease $(p<0.0001)$ in the frequency of micronuclei in binucleated cell to be $0.72+0.0262$ / BN cells at $0 \mathrm{~h}$ where as $28.85 \%$ inhibition in micronuclei when compared with $3 \mathrm{~Gy}$ gamma irradiation alone. However a decrease in the frequency of micronuclei in binucleated cell are found to be $0.98+0.0052 / \mathrm{BN}$ cell for $24 \mathrm{~h}$ although the decrease was not statistically significant $(\mathrm{p}<0.14)$ where as Ranitidine showed $2.88 \%$ inhibition in micronuclei when compared with 3Gy gamma irradiation alone.

Table III. Frequency of Micronuclei analyzed in human lymphocytes following gamma irradiation in the absence or presence of Famotidine (FAM) and Ranitidine (RAN) at $0 \mathrm{~h}$ and $24 \mathrm{~h}$ among 6 donors is depicted.

\begin{tabular}{|c|c|c|c|c|c|c|c|c|}
\hline Donors & & 1 & 2 & 3 & 4 & 5 & 6 & Mean + SE \\
\hline & Total No of BN cells & MN/cell & MN/cell & MN/cell & MN/cell & MN/cell & MN/cell & \\
\hline Control & 1000 & 0.005 & 0.004 & 0.003 & 0.003 & 0.004 & 0.005 & \\
\hline FAM 0h & 1000 & 0.005 & 0.005 & 0.004 & 0.003 & 0.004 & 0.006 & \\
\hline FAM $24 \mathrm{~h}$ & 1000 & 0.004 & 0.004 & 0.006 & 0.003 & 0.003 & 0.004 & \\
\hline RAN 0h & 1000 & 0.005 & 0.004 & 0.005 & 0.006 & 0.006 & 0.004 & \\
\hline RAN 24h & 1000 & 0.004 & 0.004 & 0.006 & 0.005 & 0.003 & 0.003 & \\
\hline 3Gy & 1000 & 1.010 & 1.040 & 0.980 & 0.960 & 1.040 & 1.030 & $1.0100+0.01366$ \\
\hline $3 \mathrm{~Gy}+\mathrm{FAM} 24 \mathrm{~h}$ & 1000 & 0.964 & 0.978 & 0.930 & 0.968 & 0.940 & 0.980 & $0.9600+0.00837$ \\
\hline $3 \mathrm{~Gy}+\mathrm{RAN} 0 \mathrm{~h}$ & 1000 & 0.772 & 0.802 & 0.722 & 0.620 & 0.720 & 0.684 & $0.7200+0.02629$ \\
\hline $3 \mathrm{~Gy}+\mathrm{RAN} 24 \mathrm{~h}$ & 1000 & 0.988 & 0.974 & 0.998 & 0.978 & 0.960 & 0.982 & $0.9800+0.00527$ \\
\hline
\end{tabular}




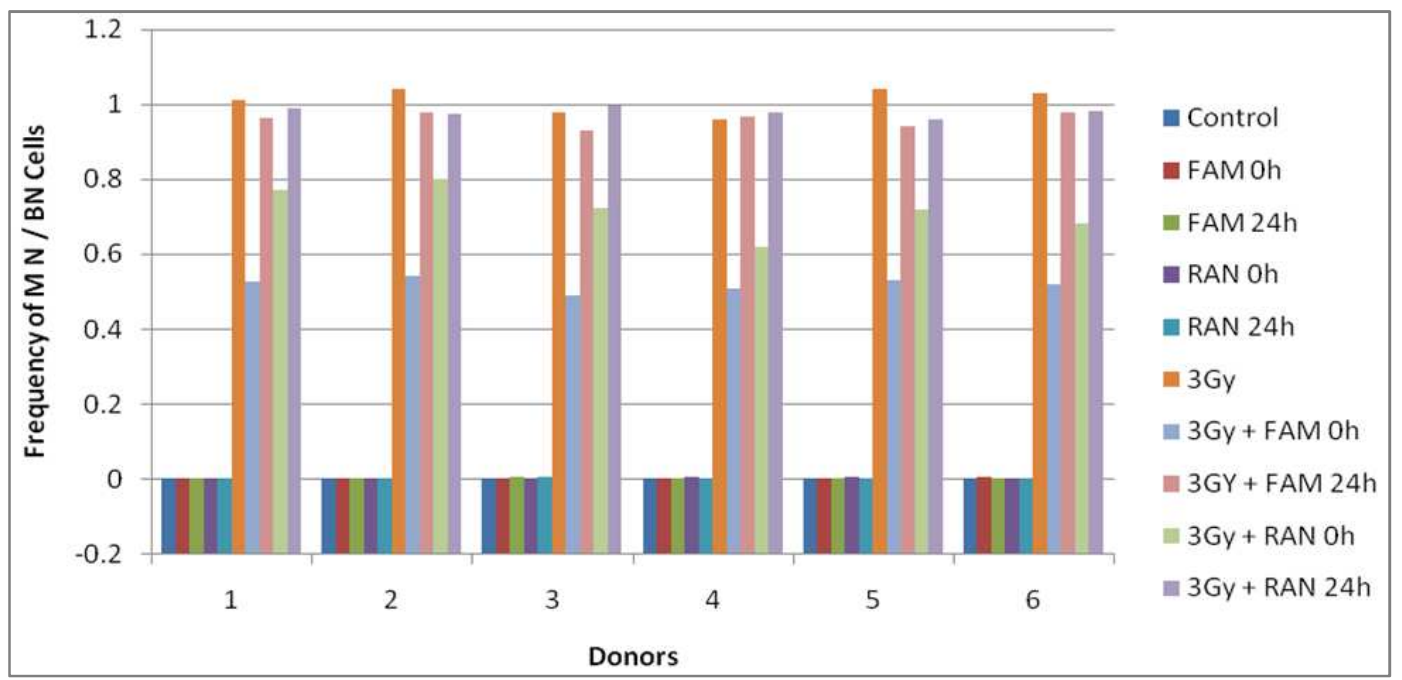

Fig. 3. Frequency of Micronuclei analyzed/BN cells in human lymphocytes following gamma irradiation in the absence or presence of Famotidine (FAM) and Ranitidine (RAN) at $0 \mathrm{~h}$ and $24 \mathrm{~h}$ in 6 donors [ Y axis represents frequency of Micronuclei per BN cells and Xaxis represents six donors].

Table IV. Percent Inhibition of Micronuclei analyzed in human lymphocytes following gamma irradiation and Famotidine (FAM) or Ranitidine (RAN) at Oh and 24 h among the six donors is depicted.

\begin{tabular}{lllll}
\hline \multicolumn{7}{c}{ \% Inhibition of MN } & & \\
\hline Donor & 3Gy + FAM 0h & 3Gy + FAM 24h & 3Gy + RAN 0h & 3Gy + RAN 24h \\
\hline 1 & 47.72 & 4.47 & 23.56 & 2.10 \\
2 & 47.93 & 5.96 & 22.88 & -1.60 \\
3 & 50.05 & 5.40 & 26.48 & -1.66 \\
4 & 48.96 & -0.008 & 35.73 & 7.60 \\
5 & 49.04 & 9.53 & 30.90 & 3.47 \\
\hline
\end{tabular}

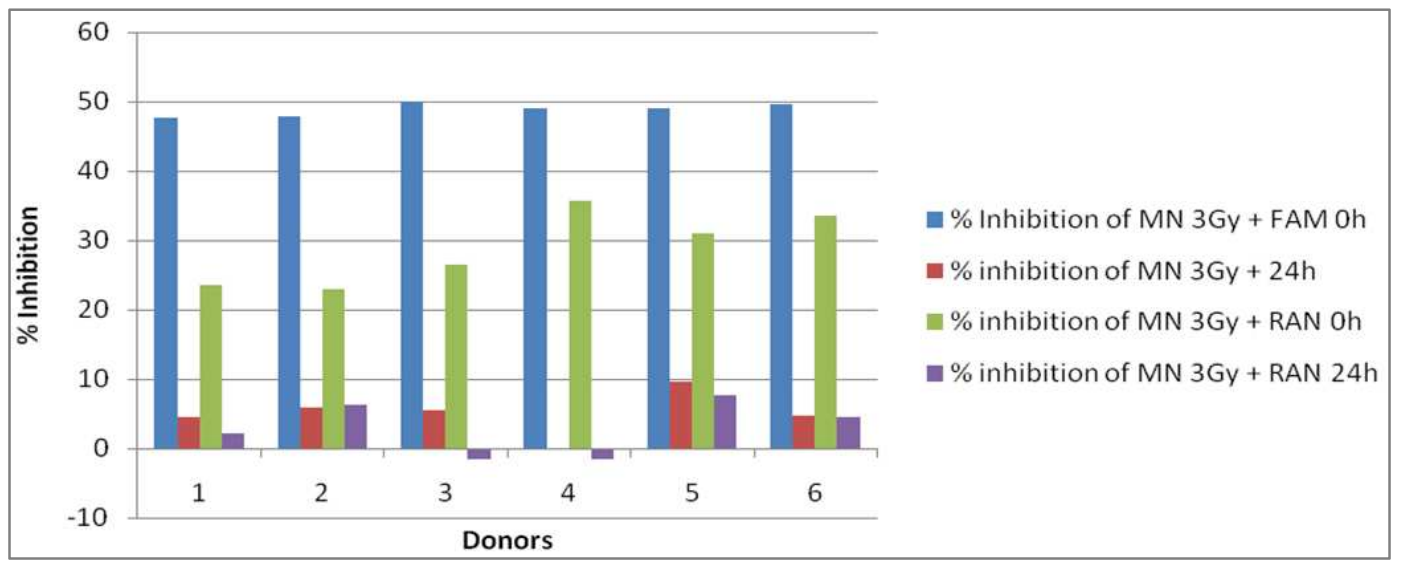

Fig. 4. Percent Inhibition of Micronuclei analyzed in human lymphocytes following gamma irradiation and Famotidine (FAM) or Ranitidine (RAN) at Oh and $24 \mathrm{~h}$ in 6 donors [ $Y$ axis represents \% inhibition and $X$ axis represents six donors].

The nuclear division index (NDI) ranged between 1.532 to 1.708 , and was determined by scoring the number of mononucleate, binucleate, trinucleate, tetranucleate and more (polynucleate) cells in 1000 viable cells.

\section{Discussion}

In the present investigation, evaluation of radioprotective effects of Histamine $\mathrm{H} 2$ receptor antagonists is comprehensively investigated; Famotidine and Ranitidine on gamma-ray induced chromosome aberration and Micronuclei in vitro in human lymphocytes of six donors. CA and CBMN formation is used as the end points. The data indicated that the control (untreated) lymphocytes, did not exhibit any type of chromosomal damage.

It is a well known fact that ionizing radiations such as Xrays and gamma rays produce biological damages/effects due their indirect-effect through formation of free radicals. A major proportion of single and double strand breaks in DNA molecule is caused by the formation of hydroxyl radicals [14, 15]. It is also observed that $-\mathrm{OH}^{-}$scavengers played an effective role in preservation of the DNA strands against 
breakage [16]. Such scavengers are known as radioprotectors which are designed compounds to reduce radiation induced damage in normal tissue on exposure to radiation. Famotidine and Ranitidine, $\mathrm{H} 2$ receptor antagonists have exerted radio protective effect in many systems such as in mouse bone marrow erythrocytes, Famotidine and Ranitidine showed radioprotective effects when applied in vivo [17]. Studies carried out by Lappena et al [18] have shown that Famotidine and Ranitidine as such do not have immunomodulatory role in the body but these drugs are potent oxygen radical scavengers. Ching et al [19] have demonstrated that histamine $\mathrm{H} 2$ receptor antagonists such as Famotidine and Ranitidine were good inhibitors of histamine - stimulated gastric acid secretion and also posses the capability for gastric acid suppression and pepsin secretion [4]. These are potent and highly powerful hydroxyl-radical scavengers. Based on the study of Ching et al [20] on $\mathrm{HOCl}$ scavenging properties of these drugs, it was concluded that the presence of sulphur atom in the compound is important for their scavenging activity.

Lymphocytes treated with Famotidine and Ranitidine at $0 \mathrm{~h}$ and $24 \mathrm{~h}$ did not show any increase in frequency of dicentric and total aberration. Ionizing radiation such as gamma radiation (3Gy) alone caused increased in chromosomal damage resulting in dicentrics, centric rings and fragment formation. Lymphocytes treated with Famotidine and Ranitidine at $0 \mathrm{~h}$ and $24 \mathrm{~h}$ after irradiation with gamma ray (3Gy) showed decrease in the frequency of dicentric and total aberration. The MN test is a reliable and effective test for the evaluation of clastogenic effects of physical and chemical agents [21, 22]. Lymphocytes treated with Famotidine and Ranitidine at $0 \mathrm{~h}$ and $24 \mathrm{~h}$ did not show any increase in frequency of micronuclei when compared with controls. 3Gy of gamma radiation exposure alone caused increase in micronuclei frequency. Lymphocytes treated with FAM and RAN at $0 \mathrm{~h}$ and $24 \mathrm{~h}$ after irradiation with gamma ray (3Gy) also showed a decrease in the frequency of micronuclei. The results and observation of the experiments conducted indicated that histamine $\mathrm{H} 2$ receptor antagonists are radioprotectors in nature when used in vitro as shown by Ghorbani and Mozdarani $[5,23]$. The mechanism in which these drugs reduce clastogenic effect of gamma-radiation is not fully understood. It might be due to their antioxidant and free radical-scavenging properties.

Reduction of the frequency of chromosomal aberrations in the lymphocytes treated with Famotidine and Ranitidine at $0 \mathrm{~h}$ and $24 \mathrm{~h}$ after irradiation with gamma ray (3Gy) indicate that drugs might reduce the clastogenic effect of radiation via radical scavenging mechanism and famotidine is more effective than the ranitidine - histamine $\mathrm{H} 2$ receptor antagonists studied.

\section{Conclusion}

Radioprotective effects of Histamine $\mathrm{H} 2$ receptor antagonists; Famotidine and Ranitidine on gamma-irradiation induced chromosome damage were observed and the drugs effectively reduced the frequency of radiation induced chromosome aberrations and micronucleus particularly at $0 \mathrm{~h}$, as compared to $24 \mathrm{~h}$. Famotidine was found to be more effective, thus these features makes it suitable for use as chemical radioprotector especially for radiotherapy patients.

\section{Funding}

This work was funded by the Department of Atomic Energy.

\section{References}

[1] Nikjoo H. Radiation Track and DNA damage. Iran. J. Radiat. Res. 2003, vol. 1: pp. 3-16.

[2] Patt H.M., Tyree E. B. et al. Cysteine protection against X irradiation. Science. 1949, vol. 110: pp. 213-214

[3] Patt H.M., Mayer S. H. et al. Radiation dose reduction by cysteine. J. Cell Comp. Physiol. 1953, vol. 42: pp. 327-341.

[4] Lipsy R.J., Fennerty B.F. et al. Clinical review of histamine H2 receptor antagonists. Arch. Int. Med. 1990, vol. 150: pp. 745-751.

[5] Ghorbani M. and Mozdarani H. In vitro radioprotective effects of histamine $\mathrm{H} 2$ receptor antagonists against gamma-rays induced chromosomal aberrations in human lymphocytes Iran. J. Radiat. Res. 2003, vol. 1(2): pp. 99-104.

[6] Mozdarani H. Radioprotective properties of histamine H2 receptor antagnonist: present and Future prospects. J. Radiat. Res. 2003, vol. 44: pp. 145-149.

[7] Krishnaja A.P. and Sharma N.K. Heterogeneity of chromosome damage in $\beta$-thalassaemia traits. An evaluation of spontaneous and gamma-ray-induced micronuclei and chromosome aberrations in lymphocytes in vitro after G0 and G2 phase irradiation. Int. J. Radiat. Biol. 1994, vol. 66: pp. 29-39.

[8] Krishnaja A.P., Sharma N.K. On the optimization and application of sister chromatid exchanges (SCEs) and cytokinesis blocked micronuclei (CBMN) in human lymphocytes for cytogenetic monitoring. In: Chauhan P.S., Gopinath P.M. editors. Environmental Mutagenesis and Carcinogenesis, Mumbai: Quest publications. 1998, pp.77-90.

[9] Fenech M. The in vitro micronucleus technique. Mutat. Res. 2000, vol. 455: pp. 81-95.

[10] Fenech M. The cytokinesis blocked micronucleus technique: a detailed description of the method and its application to genotoxicity studies in human population. Mutat. Res. 1993, vol 285: pp. 35-44.

[11] ISCN. International system of cytogenetic nomenclature for acquired chromosome aberrations. Harnden D.G. and Klinger H.P. (eds.), Published in collaboration with Cytogenetic and Cell Genetics, Karger, 1985, pp. 66-73.

[12] International Atomic Energy, Agency. Biological Dosimetry: Chromosomes aberrations analysis for dose assessment, I.A.E.A. Vienna Technical documents. 2001, vol. 405.

[13] Fenech M. Cytokinesis-block micronucleus cytome assay. Nature Protocols. 2007, vol. 2: pp. 1084-1104. 
[14] Cole R.J. and Taylor N. Short term tests for transplacentally active carcinogens. I. Micronucleus formation in fetal and maternal mouse erythroblasts. Mutat. Res. 1981, vol. 80: pp.141-57.

[15] Uma Devi P. and Sharma A.S. Mouse bone marrow response to low doses of whole-body gamma irradiation: induction of micronuclei. Int. J. Radiat. Biol., 1990, vol. 57: pp. 97-101.

[16] Billen D. The role of hydroxyl radical scavengers in preventing DNA strand breaks induced by $\mathrm{X}$ irradiation of toluene-treated E. coli. Radiat. Res. 1984, vol. 97: pp. 626629 .

[17] Mozdarani H. and Gharbali A. Radioprotective effects of Cimetidine in mouse bone marrow cells exposed to gamma rays as assayed by the micronucleus test. Int. J. Radiat. Biol. 1993, vol. 64: pp. 189-194.

[18] Lapenna D., DEgioia S. et al. H2 receptor antagonists are scavengers of oxygen radicals. Exp. J. Clin. Invest. 1994, vol. 24: pp. 479-481.
[19] Ching T.L., Haenen G.R.M.M. et al. Cimetidine and other H2 receptor antagonists as powerful hydroxyl radical scavengers. Chem. Biol. Interact. 1993, vol. 86: pp. 119-127.

[20] Ching T.L., Jong J.D. et al. Structural characteristics of histamine $\mathrm{H} 2$ receptor antagonists that scavenge hypochlorous acid. Eur. J. Pharm. 1994, vol. 268: pp. 89-93.

[21] Heddle J.A., Cimino M.C. et al. Micronuclei as index of cytogenetic damage: past, present and future. Environ. Mol. Mutagen. 1991, vol. 18: pp. 277-91.

[22] Jenssen D. and Ramel C. The micronucleus test as part of a short-term mutagenicity test program for the prediction of carcinogenicity evaluated by 143 agents tested. Mutat. Res., 1980, vol. 75: pp. 191-202.

[23] Shahidi M, and Mozdarani H. Potent radio protective effect of therapeutic doses of ranitidine and famotidine against gammaray induced micronuclei in vivo. Iran. J. Radiation Research 2003, vol. 1 (1): pp. 29-35. 